\title{
Building an electronic knowledge test for the handball course for the students of the Faculty of Education University of Sadat City
}

\section{${ }^{1}$ Hayam Abd Alrehem Alashmawy Introduction and research problem}

The progress of nations is measured by the strength of the educational system, and its outputs must be of a high quality, through the preparation of highly qualified individuals who are capable of developing the society and have high flexibility to develop themselves and cope with modern technological and informational changes, There is no doubt that this depends on the quality of the means of measurement and educational evaluation, which helps in making constructive decisions at all levels and stages of the educational process.

The ICT revolution has transformed the world today into a small e-village where temporal and spatial barriers are eroding. This has forced educational institutions to provide solutions to take advantage of the ICT development and employ it in the educational process in line with its goals and traditions.
Increasing the efficiency of the outputs of the educational process, the integration of technology in the process of teaching and learning is no longer a luxury, but has become a vital requirement for the development of educational structures and structures, because the technology of a qualitative leap in the rework of all work decisions The instruction of measuring achievement through testing and construction in the light of the standards are based on scientific grounds. (11: 329)

The revolution of information technology has changed the role of faculty member in the university under the e-learning system to planning the educational process and design e-learning environments, and evaluation and became a member of the faculty of the university more than ever before dealing with these technologies because of its importance in the

${ }^{1}$ Lecturer at the Faculty of Physical Education, Sadat City University Assiut Journal For Sport Science Arts 
educational

process, Universities in light of this increasing progress day after day, as well as increasing the burden on the faculty as a result of the steady increase in the number of students, which necessitated the continuation of professional growth on the one hand and the choice and design of educational attitudes on the part of Other. (3: 104)

The modern view of education emphasizes that evaluation and education are closely related. The learning process can be described as a system of interactive, interrelated workshops that affect each other. These include (input - activities and processes - outputs - calendar and feedback) As a control device in the entire educational system; and therefore is responsible for the course of the educational process and direction of the right direction through the feedback provided by; in order to achieve the completion of this system, and then developed; therefore, the evaluation is not an end to issue the verdict and the end of it It is a way helps to know the impact of what has been planned and implemented teaching and learning processes, and through which to identify the most power and strengthening points, avoiding vulnerabilities and repair. (15:2)

The real success of a student who regularly exercises sport combines sports and cognitive aspects of sports activity, and that the learning process is not limited to dynamic learning and skills, but also includes knowledge and information gained in relation to sports activity $(1: 2)$

In this sense, the cognitive aspect is one of the important pillars of the development of physical education and sports programs. It also reflects a distinct cultural and civilization face that contemporary man must be aware of. Knowledge plays an important role and demand in its transmission through the process of cultural communication through mechanisms and methods. Is acquired by education, education and education, so that the individual learner practice or viewer to understand and know and absorb a certain amount of mathematical knowledge about the type of sports activity 
practiced first and then practiced second, mathematical knowledge is no longer a byproduct of the curriculum of physical education, Knower essential. (6: 266)

The knowledge field is one of the important pillars for the development of sports education programs. It also reflects a distinctive cultural face that contemporary man must be aware of. Knowledge plays an important role in transmitting cultural processes through its mechanisms and methods. Knowledge is not inherited but acquired by education and education. The educated individual must exercise or watch to understand and know a degree of mathematical knowledge about the type of exercise that is practiced first and then practiced secondly. Mathematical knowledge is no longer merely a by-product of the mathematical education curriculum but has become a basic instruction. (7:2)

The tests have an important role in the educational process. The results determine the quantity and quality of the educational outcomes that have been achieved. As tests are one of the means of measurement, they are not an end in themselves but rather an integral part of the educational process. In the present and future of students, such as moving from one classroom to another, or even directing a particular subject (2: 103)

The electronic tests and question banks are among the most important tools for developing the educational calendar under the technological innovations, which in turn helps in developing the educational process since the tests in its present form reflect many shortcomings. The electronic tests and question banks aim to achieve the objectivity of measurement and its rates, In the development of the educational process. (11:329)

The researcher believes that electronic cognitive tests may be one of the most important means of cognitive measurement at different levels. It is also designed to identify the cognitive aspects of the type of activity practiced, as well as reorganize the materials and educational goals to achieve specific 
cognitive purposes and give them to students through the practice of works of a specialized nature, As a result of the tremendous technological progress and the development of the era of technology and informatics, which has been reflected in the ability of students to use the devices and modern communication mechanisms of computers, mobile devices and Internet, and During the study of the handball course, the researcher decided to create an electronic cognitive test for the handball course for fourth year students at the Faculty of Physical Education. University of Sadat City.

The importance and need of research:

- Trying to build an electronic knowledge test aimed at measuring the amount of proceeds in the field of handball from the information and knowledge of the students of the Faculty of Physical Education.

- Evaluation of those outcomes and work to improve the cognitive aspect of the process of learning progress and development provides the teacher and learner continuous assessment.

- The ability to adapt to work in the age of technology adds excitement and suspense to the educational process.

Search goal

\section{The aim of the research}

The research aim building an electronic a cognitive test for the handball course for the students of the first division of the Faculty of Physical Education, Sadat City University.

\section{Search query}

Does the cognitive test measure the cognitive aspects of the handball course for firstgraders?

\section{Search terms}

\section{Electronic tests}

"Tests performed by computer technologies and networks" (5: 225)

\section{Reference studies}

The researcher used the descriptive approach. The most important results were the validity of the test in its final form. The test included 43 words.

The study used the descriptive approach, which was developed by the University of Umm al-Qari in Makkah, The most important 
results were that the test consisted of (3) difficulty levels, (3) axes for each difficulty, and the number of test questions in its final form was (168), 82 of which were true and wrong and 86) Valid phrases were selected based on the highest scientific coefficients (difficulty discrimination - Ease - honesty - stability), and the time of the test as a whole (114) minutes.

The researcher used the descriptive method. The sample consisted of (77) player and player Sword fighters. The most important results were the validity of the electronic test with its variables to measure the behavior of the fencing agents of the sword.

The researchers used the descriptive approach. The sample included 20 new karate referees. The most important results were the validity of the proposed electronic scale. In addition, In estimating the level of motor memory kata in karate teachers, there are differences between kata judges in the level of motor memory, there is a direct correlation between the level of kinetic memory and decisions of kata judges in karate.
Martins K (2010) (18) studied the design of a technical test using interactive software to measure the response speed of American students. The researcher used the experimental method. The sample included 40 laboratories. The most important results were the validity of the test in measuring the speed of the simple reaction of the two laboratories, There were statistically significant differences in the rate of simple reaction between the two groups in favor of the secondary group, the response to colors and shapes was 0.13 seconds higher than the response to sounds.

The researcher used the descriptive approach. The sample included 40 female students from the fourth division (Education Division), Faculty of Education (2009). The study was designed to measure the cognitive achievement of the defensive and skillful part of handball using computer. Alexandria University was the most important results of the test designed to distinguish between the levels of students sample research. 
Search procedures

First: Research Methodology

The researcher used the descriptive approach because of its relevance to the nature of the research.

Second: The research community

The research society included the students of the first troupe of the Faculty of Physical Education- Sadat City University and enrolled in the academic year (2017 AD2018) of 207 students.

\section{Third: - Research Sample}

Basic Study Sample:

The sample of the research was randomly selected from the students of the first troupe of the Faculty of Physical Education - Sadat City University. The number of female students was 150 $(72.46 \%)$ and enrolled in the academic year (2017 - 2018).

2- Sample of the exploratory study:

A- Sample of preliminary exploratory research:

The sample of the first pilot study was chosen from the students of the fourth troupe (40) students with the aim of:
- Identification of the validity of the cognitive test according to the factors (ease, difficulty, discrimination).

- Calculation of scientific transactions to test cognitive achievement (honesty, persistence).

B- Sample of the second exploratory research:

The sample of the second pilot study was selected from the students of the first troupe of 40 students with the aim of:

- Recognition of the students' understanding of the test and their comprehension of the vocabulary.

- The clarity of the way to deal with the test.

Steps to build the online cognitive test "under consideration"

The researcher studied the related studies such as the study of Han Hang 2011 (17), van Van2012 study (20), the study of the 2012 Ghobishi 2012, 15 Timmers 2013 study (19), the study of Abdul Hadi Al-Jarrah 2013 (10) 2017 (11) The researcher reached the stages of design of electronic tests and table (1) illustrates these stages:

Table (1) 
Stages of building the online cognitive test

\begin{tabular}{l|l|l|l|l}
\hline \hline Phase & \multicolumn{4}{|c}{ includes } \\
\hline \hline Initial & $\begin{array}{l}\text { Objective } \\
\text { Identification }\end{array}$ & $\begin{array}{l}\text { Content } \\
\text { Analysis } \\
\text { Determining }\end{array}$ & the test axes & Determining \\
\hline Second & $\begin{array}{l}\text { Determination } \\
\text { of the relative } \\
\text { importance of } \\
\text { test axes }\end{array}$ & $\begin{array}{l}\text { Preparation } \\
\text { and } \\
\text { formulation } \\
\text { of test terms }\end{array}$ & $\begin{array}{l}\text { Preparion of } \\
\text { questions } \\
\text { test } \\
\text { instructions }\end{array}$ \\
\hline $\begin{array}{l}\text { The } \\
\text { third } \\
\text { the test }\end{array}$ & $\begin{array}{l}\text { Rey to correct } \\
\text { of the initial } \\
\text { image of the } \\
\text { test }\end{array}$ & $\begin{array}{l}\text { Image of the } \\
\text { test after the } \\
\text { expert } \\
\text { survey }\end{array}$ & $\begin{array}{l}\text { Calculation of } \\
\text { transactions } \\
\text { ease, } \\
\text { difficulty and } \\
\text { discrimination }\end{array}$ \\
\hline Fourth & $\begin{array}{l}\text { Determination } \\
\text { of test time }\end{array}$ & $\begin{array}{l}\text { Scientific } \\
\text { transactions } \\
\text { (honesty } \\
\text { and } \\
\text { persistence) }\end{array}$ & The third image of the test \\
\hline Fifth & Conversion of paper test to electronic test \\
\hline \hline
\end{tabular}

\section{The first stage}

\section{A- Goal Setting:}

The objective of the test was determined according to the goals and objectives of the research which is to measure the level of cognitive achievement of the students (the research sample) on the information and knowledge of the handball course.

\section{B - Content Analysis:}

The researcher analyzed the content of the course (description of the course) for a ball
Hand, which the sample of the research study in detail to include the cognitive test the most important topics, which are emphasized during the teaching process.

\section{C - Identification of the test} axes:

The researcher identified the axes of the test by:

- Refer to the curriculum for the first troupe (description of the course) and approved by the College Council where it 
examines the offensive skills of the band (Altntit, receipt and scroll, the correction of the jump to the top, correction of the long jump)

- Return to scientific studies and references Kamal Darwish and others 1999 (13), Mounir Gerges 2004 (14), Salim Abdul Majid Jazazi 2016 AD (9) The researcher reached the following axes:

\section{-History of Handball.}

- Basic skills. -Handball Law.

2. Phase II

Determine the relative importance of the test axes:

The researcher presented the four axes on (5) experts from the faculty members specialized in handball in the

\section{Table (2)}

The relative importance of the test of knowledge testing according to the opinions of the expert

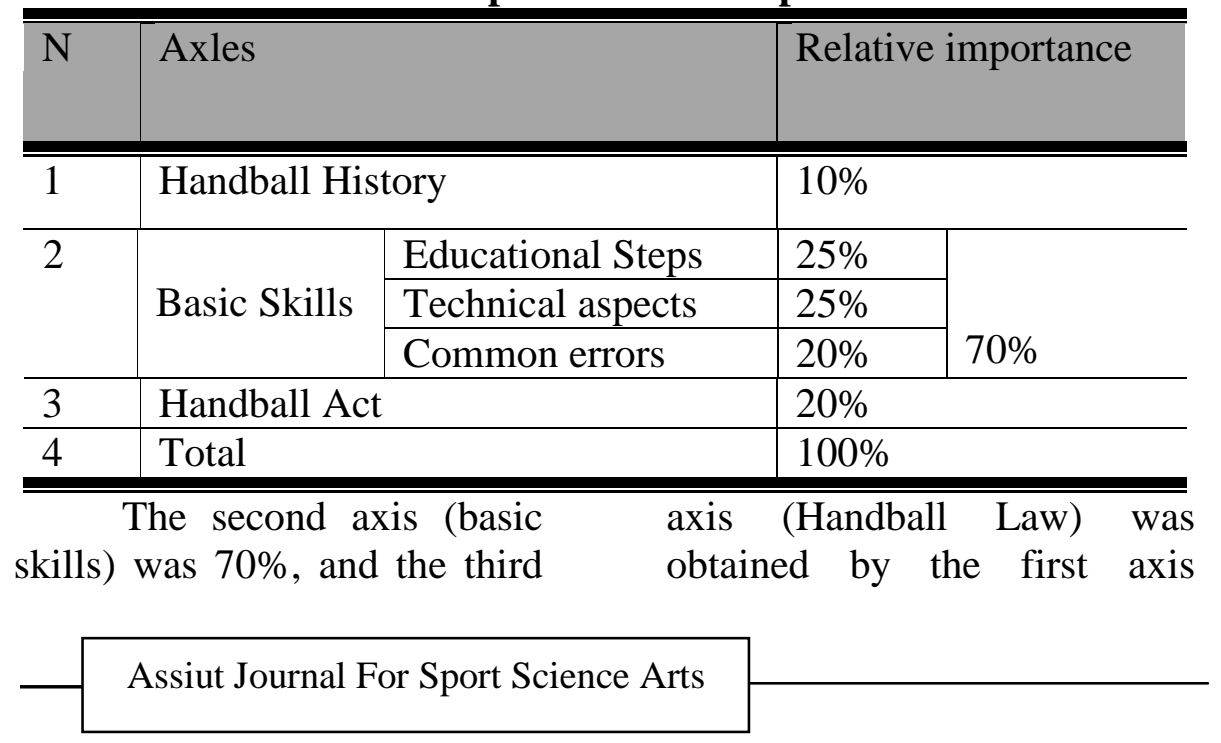

faculties of physical education so that the expert has the following conditions:

-The faculty member must have a doctorate degree in physical education in the field of handball.

- To have at least 10 years of experience in teaching and training handball facility (1) in order to express opinion in the desired axes and measure them as well as propose what is added or deleted from them in dimensions and also determine the relative importance of these dimensions and objectives in each axis of the test Annex (2) and Table (2) illustrate the relative importance of the knowledge testing axes according to the opinions of the experts. 
(Handball History) Aliash (20\%).

\section{Preparation and formulation} of test terms:

The researcher has written the vocabulary of the questions of the cognitive test after reviewing the following research, studies and scientific references: "Amin Al-Khuli, Mahmoud Annan" (1999) (4), Salim Abdul Majeed Al-Jazazi 2016 (9) "The researcher formulated them in the form of questions, and divided them on the three previous axes Table (3) according to the relative importance of each axis.

Table (3)

The number of vocabulary according to the relative importance of each axis

\begin{tabular}{|c|c|c|c|c|c|c|}
\hline $\mathbf{N}$ & \multicolumn{2}{|c|}{ Axles } & \multicolumn{2}{|c|}{$\begin{array}{c}\text { Relative } \\
\text { importance }\end{array}$} & \multicolumn{2}{|c|}{$\begin{array}{l}\text { Number of questions } \\
\text { according to relative } \\
\text { importance }\end{array}$} \\
\hline 1 & \multicolumn{2}{|c|}{ Handball History } & \multicolumn{2}{|l|}{$10 \%$} & \multicolumn{2}{|l|}{6 Questions } \\
\hline \multirow[t]{3}{*}{2} & \multirow{3}{*}{$\begin{array}{l}\text { Basic } \\
\text { Skills }\end{array}$} & $\begin{array}{c}\text { Educational } \\
\text { Steps }\end{array}$ & $25 \%$ & \multirow{3}{*}{$70 \%$} & 15 Questions & \multirow{3}{*}{$\begin{array}{c}42 \\
\text { Questions }\end{array}$} \\
\hline & & $\begin{array}{l}\text { Technical } \\
\text { aspects }\end{array}$ & $25 \%$ & & 15 Questions & \\
\hline & & $\begin{array}{l}\text { Common } \\
\text { errors }\end{array}$ & $20 \%$ & & 12 Questions & \\
\hline 3 & \multicolumn{2}{|c|}{ Handball Act } & \multicolumn{2}{|l|}{$20 \%$} & \multicolumn{2}{|l|}{12 Questions } \\
\hline
\end{tabular}

(C) Identification of the type of questions:

The researcher chose the types of questions that fit the possibilities of the site to be prepared by the test (multiple choice, right and wrong)

Preparation of test instructions:

The researcher put the instructions of the test so that they are simple and clear to the students with a statement of how to answer the questions, and included the data for the students in terms of (name grade - the academic year).

\section{Phase III}

The key to correcting the test:

One score for each test question was calculated. Since the total number of questions (60) is a question, the major end of the test is (60) degrees, where one score is allocated for 
each correct answer, and zero for questions left without answers or wrong answers.

B - Preparation of the preliminary image of the test:

The researcher presented the initial test for the cognitive test, which reached (60) question. The researcher presented the test in its preliminary form attached (3) to the number of (5) experts in the faculties of physical education. (1)
- Rewrite any of the test questions. - Add appropriate questions.

- Delete what they see as inappropriate questions. - The extent to which the type of questions included in the test is appropriate

- The clarity of the test instructions. - The suitability of the test correction key.

The following table shows the results of the presentation of the preliminary image of the test on the experts:

Table (4)

The results of the presentation of the initial image (the first picture) to test the knowledge achievement of the experts

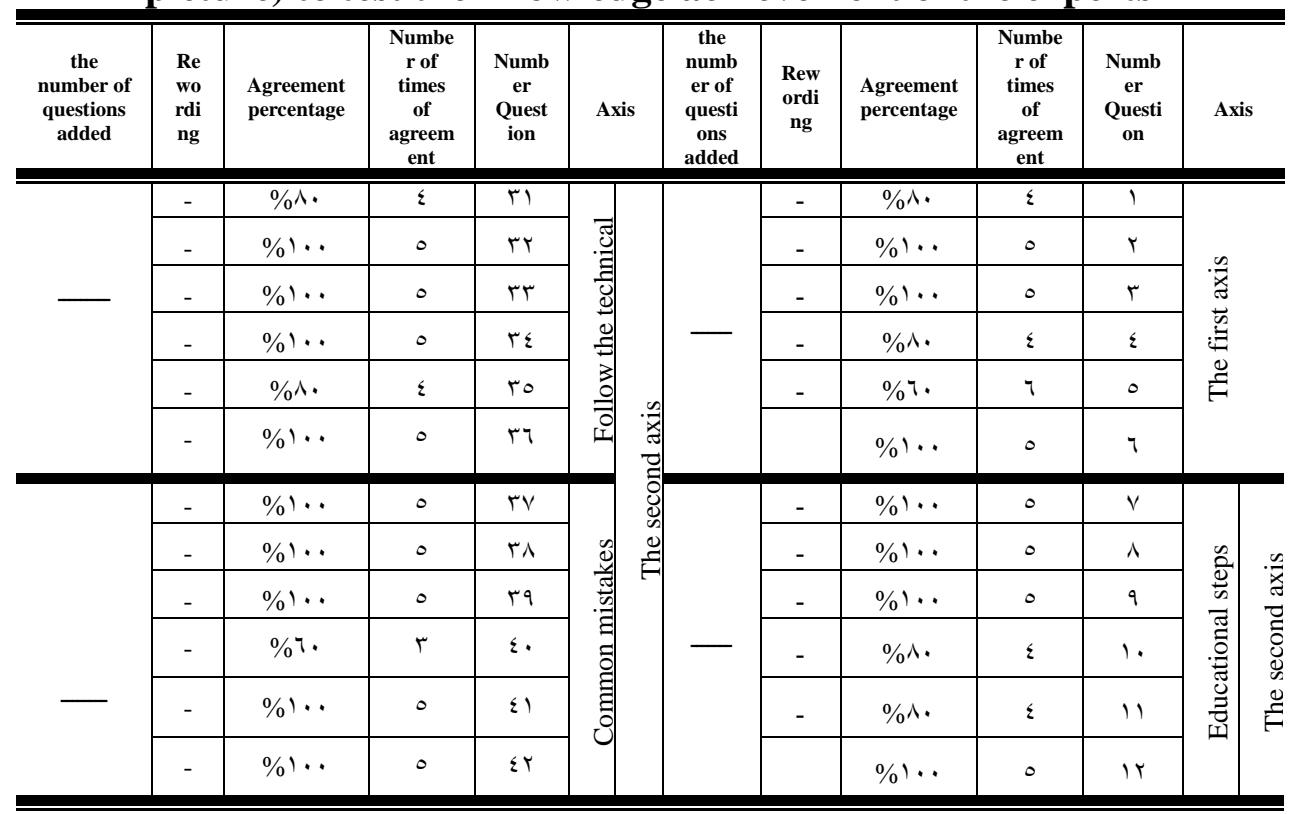

Follow Table (4) 
The results of the presentation of the initial image (the first picture) to test the knowledge achievement of the experts

\begin{tabular}{|c|c|c|c|c|c|c|c|c|c|c|c|}
\hline $\begin{array}{c}\text { the } \\
\text { number of } \\
\text { questions } \\
\text { added }\end{array}$ & $\begin{array}{l}\text { Re } \\
\text { wo } \\
\text { rdi } \\
\text { ng }\end{array}$ & $\begin{array}{l}\text { Agreement } \\
\text { percentage }\end{array}$ & $\begin{array}{c}\text { Numbe } \\
\text { r of } \\
\text { times } \\
\text { of } \\
\text { agreem } \\
\text { ent }\end{array}$ & $\begin{array}{c}\text { Numb } \\
\text { er } \\
\text { Quest } \\
\text { ion }\end{array}$ & Axis & $\begin{array}{c}\text { the } \\
\text { numb } \\
\text { er of } \\
\text { questi } \\
\text { ons } \\
\text { added }\end{array}$ & $\begin{array}{c}\text { Rew } \\
\text { ordi } \\
\text { ng }\end{array}$ & $\begin{array}{l}\text { Agreement } \\
\text { percentage }\end{array}$ & $\begin{array}{c}\text { Numbe } \\
\text { r of } \\
\text { times } \\
\text { of } \\
\text { agreem } \\
\text { ent }\end{array}$ & $\begin{array}{c}\text { Numb } \\
\text { er } \\
\text { Questi } \\
\text { on }\end{array}$ & Axi \\
\hline & - & $\% 1 \ldots$ & 0 & $\varepsilon r$ & & & - & $\% 1 \ldots$ & 0 & $1 T$ & \\
\hline & - & $\% \wedge$. & $\varepsilon$ & $\varepsilon \varepsilon$ & & & - & $\% 1 \ldots$ & 0 & $1 \varepsilon$ & \\
\hline & - & $\% 1 \ldots$ & 0 & $\leqslant 0$ & & & - & $\% 1 \ldots$ & 0 & 10 & \\
\hline & - & $\% 1$. & 0 & $\leqslant 7$ & & & - & $\% 1 \ldots$ & 0 & 17 & \\
\hline & - & $\% \wedge$. & $\varepsilon$ & $\varepsilon V$ & & & & $\% 1 \ldots$ & 0 & iv & \\
\hline & - & $\% 1$. & 0 & $\varepsilon \wedge$ & & & - & $\% \wedge$. & $\varepsilon$ & 11 & \\
\hline & - & $\% 1$. & 0 & $\varepsilon 9$ & \multirow{12}{*}{ 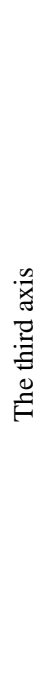 } & & - & $\% 1 \ldots$ & 0 & 19 & \\
\hline & - & $\% 1 \ldots$ & 0 & 0. & & & - & $\% 1$. & 0 & r. & \\
\hline & - & $\% 1$. & 0 & 01 & & & & $\% 7$. & $r$ & YI & \\
\hline & - & $\% 1 \ldots$ & 0 & or & & & - & $\% 1$. & 0 & rr & \multirow{9}{*}{ 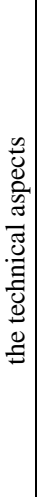 } \\
\hline & - & $\% \wedge$. & $\varepsilon$ & or & & & - & $\% 1 \ldots$ & 0 & rr & \\
\hline & - & $\% 1$. & 0 & of & & & - & $\% 1 \ldots$ & 0 & $r \varepsilon$ & \\
\hline & - & $\% 1$. & 0 & 00 & & & - & $\% 1$. & 0 & ro & \\
\hline & - & $\% 1 \ldots$ & 0 & 07 & & & & $\% \wedge$. & $\varepsilon$ & rt & \\
\hline & - & $\% 1 \ldots$ & 0 & or & & & - & $\% 1 \ldots$ & 0 & $r V$ & \\
\hline & - & $\% \wedge$. & $\varepsilon$ & $0 \wedge$ & & & - & $\% 1 \ldots$ & 0 & rA & \\
\hline & - & $\% 1$. & 0 & 09 & & & & $\% 1$. & 0 & rq & \\
\hline & - & $\% 1 \ldots$ & 0 & 7. & & & - & $\% 1 \ldots$ & 0 & r. & \\
\hline
\end{tabular}

The number of questions $(5,21,40)$ was excluded as shown in Table (4). These questions were less than the percentage of the researcher's satisfaction.

The percentage of the agreement of experts on the following:
- The appropriate range of questions (in terms of: right and wrong - multiple choice) $(100 \%)$.

- The clarity of the test instructions (100\%).

- How appropriate is the test correction key (in terms of: one degree for the correct answer, 
zero for unanswered questions or wrong answers) $(100 \%)$

$\mathrm{C}$ - Image of the test after the expert opinion: -

The researcher came to the second picture of the cognitive test attached (4), where the test in its second form (after the experts' poll) included (57) question.
This is the image of the test that will be applied to the sample of the exploratory study in order to determine the validity of the test (coefficients: ease - difficulty discrimination) in addition to the identification of its scientific transactions (honesty -Stability)

Table (5)

Characterization of the cognitive achievement test in its second form after the expert opinion

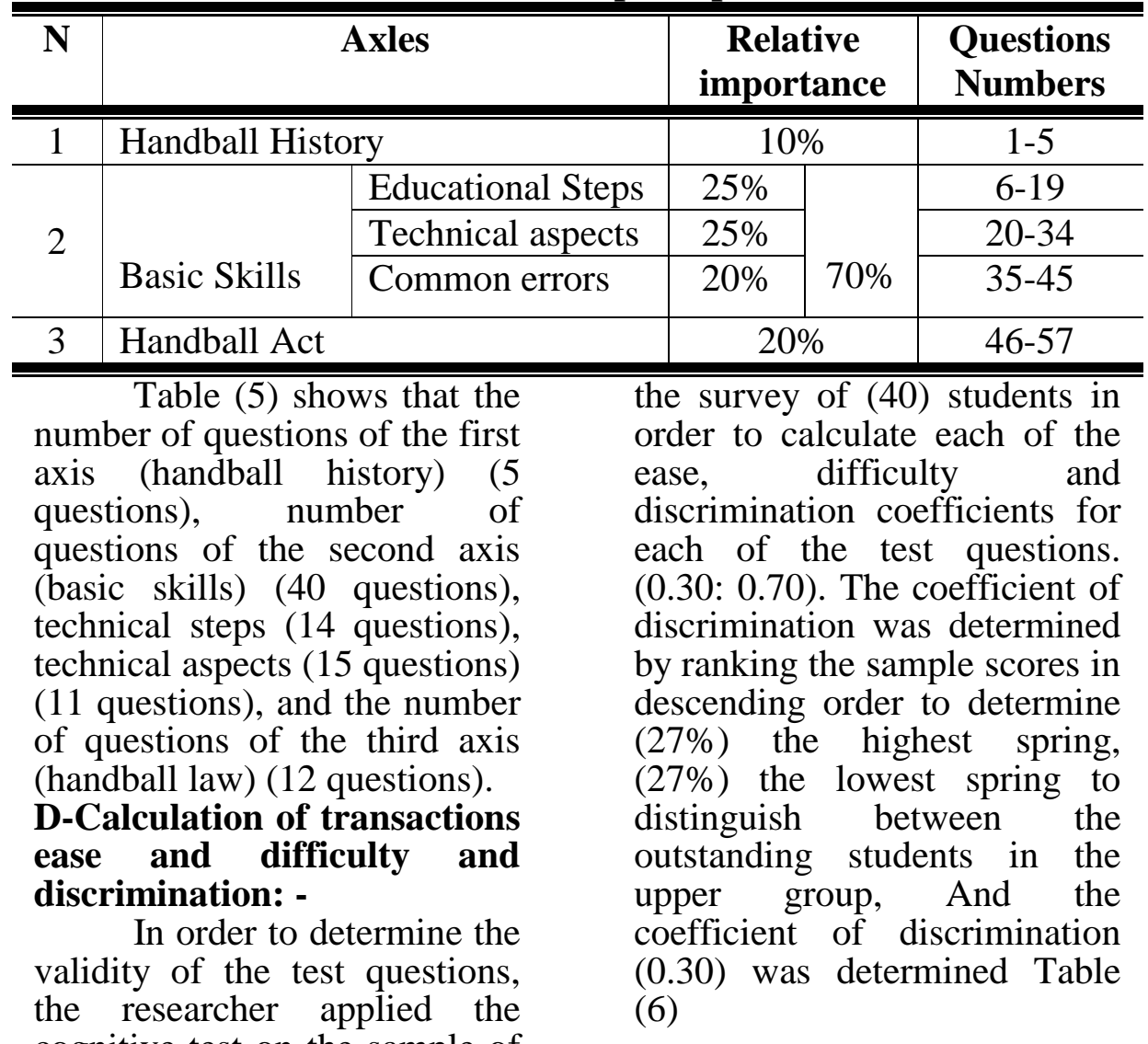
cognitive test on the sample of 
Table (6)

Ease, difficulty and discrimination coefficients for the test of cognitive achievement

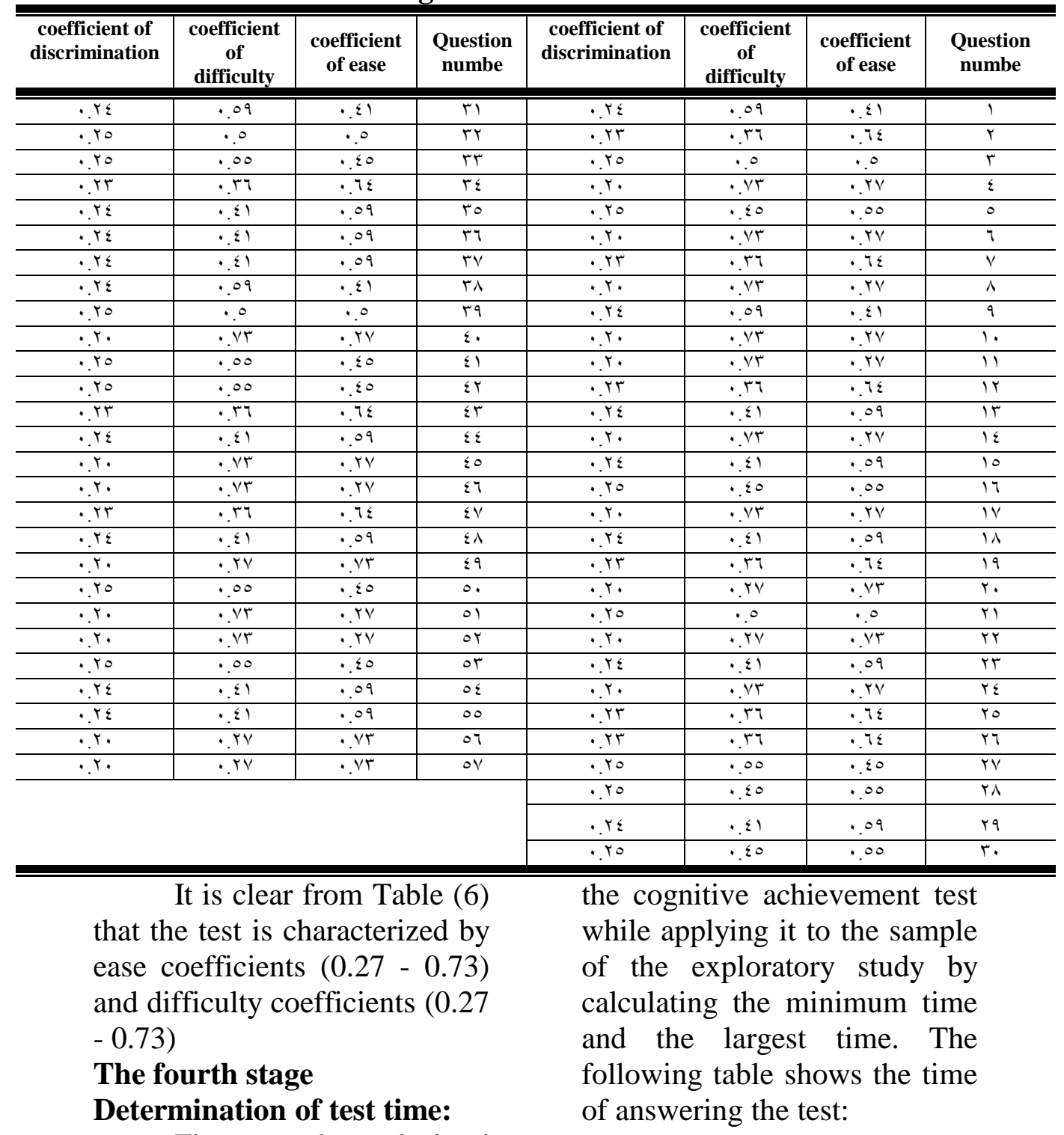

The researcher calculated the appropriate time to answer 
Table (7)

Time to answer the test

\begin{tabular}{|c|c|c|c|c|}
\hline \multirow{2}{*}{$\begin{array}{c}\text { Average } \\
\text { time }\end{array}$} & \multirow{2}{*}{ Total } & \multicolumn{2}{|c|}{ Experimental time } & \multirow{3}{*}{$\begin{array}{l}\text { Test } \\
\text { time }\end{array}$} \\
\hline & & more time & Less time & \\
\hline $30 \mathrm{~m}$ & $60 \mathrm{~m}$ & $40 \mathrm{~m}$ & $20 \mathrm{~m}$ & \\
\hline
\end{tabular}

Table (7) shows that the average response time is 20 minutes.

B - Calculation of scientific

transactions

consistency): -

- The judges ratified: -

The researcher presented the test to the number of (5) experts in the faculties of physical education facility (1), and the experts indicated that the test is honest and measures the aspects that were developed for them.

- True internal consistency: -
The researcher calculated the validity of the test on a sample of (40) female students of the fourth division on Tuesday, 20/2/2018 through

- Find the correlation coefficient between the degree of each statement, the sum of the axis to which it belongs and the total sum of the test

- Find the correlation coefficient between each axis and the total sum of the test

Table (8)

The coefficient of correlation between the degree of each statement and the sum of the axis to which it belongs The total test

\begin{tabular}{|c|c|c|c|c|c|c|c|c|}
\hline $\begin{array}{c}\text { coefficient } \\
\text { The } \\
\text { correlation } \\
\text { with the } \\
\text { total mass } \\
\text { of the test }\end{array}$ & $\begin{array}{c}\text { correlation } \\
\text { coefficient } \\
\text { with axis }\end{array}$ & $\begin{array}{l}\text { number } \\
\text { Question }\end{array}$ & Axis & $\begin{array}{c}\text { coefficient } \\
\text { The } \\
\text { correlation } \\
\text { with the } \\
\text { total mass } \\
\text { of the test }\end{array}$ & $\begin{array}{c}\text { correlation } \\
\text { coefficient } \\
\text { with axis }\end{array}$ & $\begin{array}{l}\text { number } \\
\text { Question }\end{array}$ & \multicolumn{2}{|c|}{ Axis } \\
\hline$\because v \leqslant q$ & .1807 & Tा & \multirow{5}{*}{ 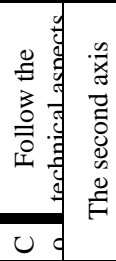 } & ..$\wedge Y Y$ & •.^9. & 1 & \multirow{5}{*}{\multicolumn{2}{|c|}{$\begin{array}{l}\frac{n}{x} \\
\frac{4}{4} \\
0\end{array}$}} \\
\hline$\cdot \wedge \wedge \wedge$ & שT & Tr & & . VKr & $\cdot \wedge \leqslant \vee$ & r & & \\
\hline סדז. & $\cdot .7 \leq \leqslant$ & זr & & .100 & $\cdot \wedge 9 \vee$ & $r$ & & \\
\hline.$\leq 11$ & $\cdot \varepsilon r r$ & $r \varepsilon$ & & וד9. & .90 . & $\varepsilon$ & & \\
\hline .711 &.$T \vee \wedge$ & ro & & $\cdot$.AVY & $\cdot \wedge \vee T$ & 。 & & \\
\hline वr. & $\because \wedge \leqslant 0$ & דr & & $.7 \times 0$ & $\cdot .7 \vee \wedge$ & 7 & \multirow{4}{*}{ 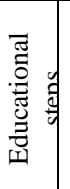 } & \multirow{4}{*}{ 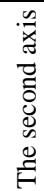 } \\
\hline$\cdot \wedge \wedge \prime$ & $\cdot \wedge \wedge \leq$ & rv & & $. V \leq r$ & $\therefore \vee 0 \leq$ & V & & \\
\hline$\cdot 1999$ & .94. & rی & &.$\wedge 11$ & $\cdot \wedge \leqslant 0$ & $\wedge$ & & \\
\hline$\cdot \wedge V Y$ & $\cdot \wedge \wedge \wedge$ & rq & & $\cdot \wedge 0 \leqslant$ & זדی. & 9 & & \\
\hline
\end{tabular}


FollowTable (8)

The coefficient of correlation between the degree of each statement and the sum of the axis to which it belongs The total test

\begin{tabular}{|c|c|c|c|c|c|c|c|}
\hline $\begin{array}{l}\text { coefficient } \\
\text { The } \\
\text { correlation } \\
\text { with the } \\
\text { total mass } \\
\text { of the test }\end{array}$ & $\begin{array}{c}\text { correlation } \\
\text { coefficient } \\
\text { with axis }\end{array}$ & $\begin{array}{l}\text { number } \\
\text { Question }\end{array}$ & Axis & $\begin{array}{c}\text { coefficient } \\
\text { The } \\
\text { correlation } \\
\text { with the } \\
\text { total mass } \\
\text { of the test }\end{array}$ & $\begin{array}{l}\text { correlation } \\
\text { coefficient } \\
\text { with axis }\end{array}$ & $\begin{array}{l}\text { number } \\
\text { Question }\end{array}$ & \\
\hline$\because \vee \wedge \wedge$ & 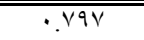 & $\varepsilon$. & & $\because V 0 \leq$ &. V०7 & 1. & \\
\hline$\because$ Vol & $\because \vee \wedge$. & $\leqslant 1$ & & $\cdot . q \cdot r$ & .915 & 11 & \\
\hline$\because v \leqslant 7$ & $\because V 0 \leq$ & $\varepsilon r$ & & IITI & אזד. & ir & \\
\hline$\because V \vee$. & $\cdot \vee \wedge \varepsilon$ & $\varepsilon r$ & & oro & $.0 \leqslant 1$ & $1 \pi$ & \\
\hline$\therefore \leqslant 70$ & $\because \leqslant 7 \wedge$ & $\varepsilon \varepsilon$ & & .0 .0 & .011 & $1 \leqslant$ & \\
\hline$\cdot \leq \leqslant 0$ & .000 & $\leqslant 0$ & & $\cdot .7 \times 1$ & $.7 \wedge \varepsilon$ & 10 & \\
\hline $.0 \vee 9$ & .019 & $\leqslant 7$ & \multirow{14}{*}{ 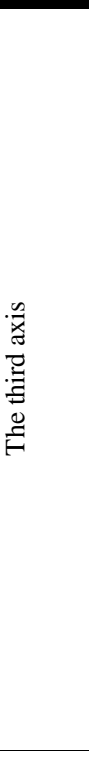 } & $\cdot .711$ & $.79 \vee$ & 17 & \\
\hline . VTo & $\cdot V \leqslant r$ & $\varepsilon V$ & & $\because \vee \vee O$ & $\therefore \vee \wedge$. & IV & \\
\hline $.0 \leq 0$ & .077 & $\leqslant 1$ & & $\cdot 7 \times 7$ & $\cdot . T \wedge 0$ & 11 & \\
\hline$\because \leqslant 71$ & $\cdot \leqslant V T$ & $\varepsilon 9$ & & $.9 r \leq$ & & 19 & \\
\hline$\cdot v \leqslant \Lambda$ & $\because \times 01$ & 0. & & $\because \leqslant Y r$ &.$\leqslant r_{0}$ & $r$. & \multirow{11}{*}{ 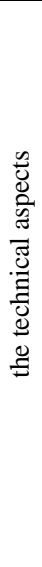 } \\
\hline . TY & $.7 r 9$ & 01 & & $\because \vee 1$. & $\cdot V \vee \leq$ & rI & \\
\hline$\cdot .119$ & $\cdot \wedge r \leq$ & or & & .0 ork & $.0 \leqslant 0$ & rr & \\
\hline $.9 r \wedge$ & $\cdot 9 \leq 1$ & or & & $\because V \vee T$ & $\because \vee \wedge \varepsilon$ & r & \\
\hline$\because T \wedge \varepsilon$ & $\cdot .7 \wedge 9$ & $0 \leqslant$ & & $\because \wedge 99$ & .911 & T纟 & \\
\hline$\cdot \wedge \leqslant 9$ & $\cdot A V Y$ & 00 & & $\because \wedge \vee \vee$ & $\cdot \wedge \wedge 0$ & ro & \\
\hline$\cdot .9 \vee \wedge$ & .99. & 07 & & $\because \wedge \leqslant 1$ & $\cdot \wedge \circ \mathrm{V}$ & rT & \\
\hline \multirow[t]{4}{*}{.$\wedge 77$} & $\cdot \Delta V Y$ & or & &.$V q^{\prime}$ & $. V \leqslant 7$ & TV & \\
\hline & & & & $\because 0 \leqslant$. & $.0 \leqslant 7$ & rA & \\
\hline & & & & $\because \leqslant 0$. &.$\leqslant 07$ & rq & \\
\hline & & & &.$\leqslant 19$ &.$\leqslant Y_{0}$ & $r$. & \\
\hline
\end{tabular}

Table (8) shows that there is a statistically significant correlation between the score of each statement, the total sum of the axis represented by the term, and the total sum of the test, which indicates the veracity of the representation of that term for the axis it represents and the test under consideration. 
Table (9)

Correlation coefficient between each axis and total test

\begin{tabular}{c|c}
\hline \hline correlation coefficient with total test & Axis \\
\hline \hline $0.788 *$ & First (Handball History) \\
\hline $0.725 *$ & scond (core skills) \\
\hline $0.730 *$ & Third (handball law) \\
\hline \hline
\end{tabular}

Table (9) shows that there is a statistically significant correlation between the degree of each axis and the total number of tests. The values ranged between 0.725 and 0.788 , indicating that they have high reliability coefficients.

- Stability of the test

The stability of the test was calculated in the period from Tuesday 20/02/2018 to
Tuesday 6/3/2018 through the calculation of the alpha kernbach coefficient and the method of application of the test and re-application to the survey sample which reached (40) students from the fourth division, Interval between the two applications (15) days, and the correlation coefficient between the two applications was found, and Table (10) shows the stability of the test

\section{Table (10)}

Alpha-Cranbach coefficient and correlation coefficients between the first application and the second application of the test "under consideration"

\begin{tabular}{|c|c|c|c|c|c|c|c|c|}
\hline \multirow{2}{*}{$\begin{array}{c}\text { The value } \\
\text { of the } \\
\text { alpha } \\
\text { coefficient }\end{array}$} & \multirow[t]{2}{*}{$\begin{array}{c}\text { correlation } \\
\text { coefficient }\end{array}$} & \multirow{2}{*}{$\begin{array}{c}\text { The } \\
\text { difference } \\
\text { between } \\
\text { the mean }\end{array}$} & \multicolumn{2}{|c|}{$\begin{array}{l}\text { The second } \\
\text { application }\end{array}$} & \multicolumn{2}{|c|}{$\begin{array}{c}\text { The first } \\
\text { application }\end{array}$} & \multirow{2}{*}{\multicolumn{2}{|c|}{ Axis }} \\
\hline & & & $\begin{array}{l}\text { standard } \\
\text { deviation }\end{array}$ & Mean & $\begin{array}{l}\text { standard } \\
\text { deviation }\end{array}$ & Mean & & \\
\hline$* . .10$ & $\overline{* * * . \wedge Y .}$ & $\because \cdot r$ & .09 & r.91 & $\cdot v \cdot$ & $\Gamma . \wedge \Lambda$ & \multicolumn{2}{|c|}{ 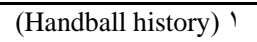 } \\
\hline$* . \wedge \vee 0$ & $* * .9 \wedge \varepsilon$ & $\because \cdot 1$ &. .74 & $1 \cdot \cdots$ & .70 & $1 \cdot \cdot 1$ & $\begin{array}{l}\text { Educational } \\
\text { steps }\end{array}$ & \multirow{3}{*}{$\begin{array}{c}r \\
\text { Basic ) } \\
\text { (skills }\end{array}$} \\
\hline$* . V T I$ & $* * .910$ & $\because \cdot r$ & $\cdot 71$ & $1 T .91$ & $\cdot V V$ & $1 \% .90$ & $\begin{array}{l}\text { Technical } \\
\text { aspects }\end{array}$ & \\
\hline$* .7 \vee 0$ & $* * . \vee 0 \leqslant$ & . rr & $1.1 T$ & Q.YT & 1.19 & 9.00 & $\begin{array}{l}\text { Common } \\
\text { errors }\end{array}$ & \\
\hline$* \cdot V ! \varepsilon$ & $* * \cdot \vee \vee \vee T$ & $\because .9$ & .94 & A. $\cdot \varepsilon$ & .91 & $\Lambda .1 T$ & \multicolumn{2}{|c|}{$(\text { Handball Act })^{r}$} \\
\hline$* .1 \times 90$ & $* * . V T V$ & $\therefore \leqslant 0$ & T. Y & $\leqslant \varepsilon .17$ & 1.97 & $\{\leqslant .71$ & \multicolumn{2}{|c|}{ Total } \\
\hline
\end{tabular}

Table (10) shows that the calculated " $t$ " value of $t$ is a statistical function indicating that there is a correlation between the first application and the second application and 
thus the stability of the test is "under consideration".

C - The third picture of the test: After calculating the coefficients of ease, difficulty, discrimination and calculation of coefficients of truthfulness and stability, the researcher reached the third picture of the cognitive test attached (5)

4- Stage 5:

\section{Conversion of paper test to electronic test:}

The researcher used the Google Forms to convert the cognitive test from its paper image to its electronic image. It is available on the following link:

https://docs.google.com/forms/ d/e/1FAIpQLSe6Q1WzMPjqJu 1khH_o66iY0I8sswS8vQ3sPly had25prdDeA/viewform

(The student can not answer more than once), and the settings were set to randomly display questions (each student has a different arrangement than the other)

The researcher created a group to apply FACE BOOK to collect the students and send the test link to them in the group.

Fifth: - Application of the electronic test on the sample exploratory: -
The researcher applied the online cognitive test on Sunday $22 / 4 / 2018$ in the college's lab on a sample of 40 female students from the first division of the Faculty of Physical Education, Sadat City University from the same research community and from outside the basic research sample after completing the course. Study the following results:

- Students understand the test and their ability to vocabulary. - Clear handling of the test.

Sixth: Statistical treatments:

The researcher used the statistical treatments suitable for the nature of the research using the program: Statistical Package for Social Sciences (SPSS) Statistical Package for the Social Science, and the following statistical treatments were used:

- Percentages.

- SMA .

- standard deviation .

- Correlation coefficient.

- correlation coefficient.

- Ease, difficulty and discrimination.

- Alpha-Cranbach coefficient.

View and discuss the results

Based on the question and the research objective, the researcher presented the results 
obtained in accordance with the data obtained. A total of (57) words were used to measure the cognitive aspect of the handball course according to the steps used in constructing the test as shown in Table (1).

The researcher applied the electronic cognitive test to 150 female students from the first division of the Faculty of Physical Education at the
University of Sadat city after completing the course on Saturday 28/4/2018 at the faculty's lab. The number of female students was 150 students $(72.46 \%) \quad$ And enrolled in the academic year (2017-2018) in order to ensure the achievement of the research question and Table (11) and Figure (1) illustrate the results of the application of the online cognitive

test

\section{Table (11)}

Statistical profile of the individuals in the research sample in the online cognitive test

\begin{tabular}{|c|c|c|c|c|c|c|}
\hline$\overline{\text { Sekwansess }}$ & $\begin{array}{l}\text { Standard } \\
\text { Deviation }\end{array}$ & Median & mean & $\begin{array}{c}\text { Unit of } \\
\text { Measurement }\end{array}$ & \multicolumn{2}{|c|}{ Axis } \\
\hline $.9 \leqslant 1$ & .117 & $\overline{\Gamma .11}$ & $r . \leqslant 0$ & Degree & \multicolumn{2}{|c|}{ (Handball history) 1} \\
\hline $.977-$ & $1 . V V$ & $1 \cdot .1 Y$ & 9.00 & Degree & $\begin{array}{l}\text { Educational } \\
\text { steps }\end{array}$ & \multirow{3}{*}{$\begin{array}{c}r \\
\text { Basic ) } \\
\text { (skills }\end{array}$} \\
\hline .071 & .90 & 1.90 & 11.11 & Degree & $\begin{array}{c}\text { Technical } \\
\text { aspects }\end{array}$ & \\
\hline 1.017 &.$\wedge 9$ & $9.4 \%$ & $9 . V V$ & Degree & $\begin{array}{l}\text { Common } \\
\text { errors }\end{array}$ & \\
\hline $1.1 \leqslant 7-$ & $1 . V A$ & 1.10 & $V . \Sigma V$ & Degree & \multicolumn{2}{|c|}{$(\text { Handball Act })^{r}$} \\
\hline.$r o v$ & $r .11$ & $\varepsilon 1.11$ & $\varepsilon 1 . \mu V$ & Degree & \multicolumn{2}{|c|}{ Total } \\
\hline
\end{tabular}

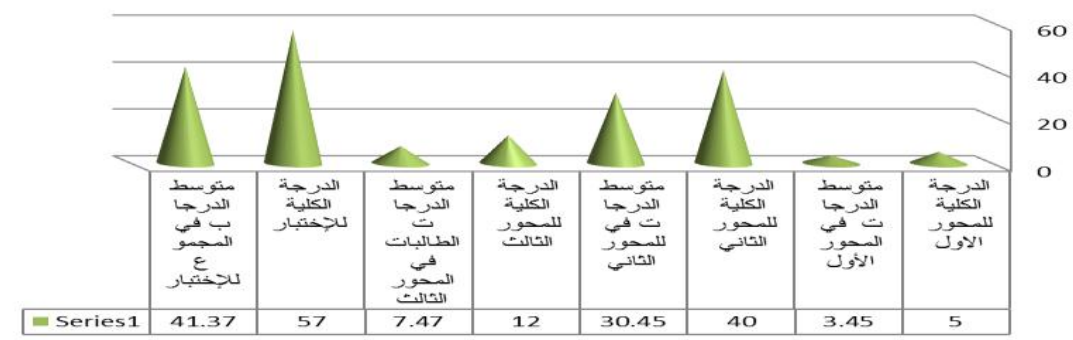

Shape (1)

Statistical profile of the individuals in the research sample in the online cognitive test 
Table (11) and the data represented in Figure (1) show the homogeneity of the research sample in the subjects of the cognitive test "Handball History, Basic Skills, Handball Law" where the values of the splicing factor were limited to $( \pm 3)$ Degree of the members of the research sample in the electronic cognitive test.

The researcher considers that electronic testing is one of the most important means of measuring the cognitive aspect and has become one of the requirements of the age in which we live. Through technological progress and development, we have to develop in different ways and means of evaluation in general and in the field of cognitive achievement in particular.

(7) in the efficiency of electronic tests in the measurement of cognitive achievement and the tremendous technological progress and the development of the era of technology and informatics, which was reflected on the ability of female students in The use of modern communication devices and devices from computers, mobile devices and Internet networks.

Thus, the answer to the research question is: "Yes, the cognitive test measures the cognitive aspects of the handball course for the students of the first division"

Conclusions and Recommendations

\section{First: Conclusions}

1- Building an electronic knowledge test for the handball course of the first girls section at the Faculty of Physical Education, Sadat City University

2. The electronic test that was designed is one of the latest techniques in handball.

(57) words, (5) words to measure the axis of history in handball, (40) words to measure the axis of basic skills in handball, (12) words to measure the axis of law in handball.

4. The test time (30) minutes.

Second: Recommendations

1 - the interest of teaching staff in general and the field of handball in particular electronic tests.

2. Use the proposed test to measure the cognitive achievement of offensive skills. 
3 - Building electronic tests for the collection of knowledge in the defense and planning in handball.

4 - Building electronic tests for the collection of knowledge of other sports.

5 - the continuous development of the processes of educational evaluation to see everything that is new.

\section{References:}

First: Arabic References

\section{1- Ibrahim Ibrahim}

Ghoneim: Building a cognitive test in boxing sport for students of the Faculty of Physical Education, Master Thesis, Faculty of Physical Education, Mansoura University, 2004.

2- Osama Said Hindawi: Effect of three designs for the response patterns on the electronic tests on the rate of immediate and deferred performance of the university students in the test, Journal of Educational Sciences, No. 3, 2010.

\section{3- Akram Fathi Mustafa:} (Education at the beginning of the third millennium: "Qualityavailability- learning for life"), the 7th International Conference from 15-16 July, Institute of Educational Studies, Cairo University, 2009
4- Amin Anwar Al-Khouli, Mahmoud Abdelfattah Anan: Mathematical (Conceptual Knowledge Mathematical Knowledge Mathematical Knowledge Tests, "Foundations and Complete Models"), Dar AlFikr Al-Arabi, Cairo, 1999.

5- Hassan

Zeitoun

Hussein: A New Vision in Education E-Learning (Concept - Issues - Application - Assessment).

6- Hamdy Mohamed El Gohary: Determination of standard levels of cognitive achievement using electronic test in volleyball for students of the Faculty of Physical Education Mansoura University, the scientific journal of Physical Education and Sports Sciences, Mansoura University, 2015.

\section{7- Khaled Farid Ziadeh:} Building a multi-disciplinary electronic knowledge test in the light of the technical and legal amendments to judo sport, Assiut magazine for the sciences and arts of physical education, No. 41, part one, Faculty of Physical Education, Assiut University, 2015 https://search.mandumah.com/ Record / 775695 
8- Duaa El-Dardiri Abu

Hassan: Designing a Test to Measure the Cognitive Achievement of the Defense and Hand-Held Defense of Computer Handball, 3rd International Scientific Conference (Towards Better Investment for Egyptian and Arab Sports), Volume 1, Number 1, Faculty of Physical Education for Boys, Zagazig University, 2009.

9- Salim Abdul Majid AlJazazi: Building a Knowledge Test for Handball Law for Students of the Faculty of Mathematical Sciences Mu'tah University, Journal of Education, Al-Azhar University, No. 171, Part II, 2016.

\section{0- Abdul Hadi Ali Al-} Jarrah: The Use of Jordanian School Teachers and their Teachers for the Eduwave System, their Attitudes towards and Impediments to their Use, Educational and Psychological Sciences Magazine, Bahrain, 2013

11- Amr Galal El Din Allam: Skills to build electronic tests in light of the quality standards of faculty members and their assistants, Journal of Technology Education -
Studies and Research, Egypt, 2017

\section{2- Fikry Fayek Soliman:} Building an electronic test to measure the behavior of the fencing officers of the sword, published doctorate thesis, Faculty of Physical Education, Mansoura University, 2013.

\section{3- Kamal Darwish, Imad} Abbas, Sami Mohamed Ali: Handball Defense, The Book Center for Publishing, Cairo, 1999.

\section{4- Mounir}

Gerges Ibrahim: handball, comprehensive training, and skill excellence, Arab Thought House, Cairo, 2004.

15- The Effect of Some Variables in the Design of Electronic Tests on the Performance and Attitudes of Sixth Grade Secondary Students, Master Thesis, Faculty of Education, Taibah University, 2012

\section{Second: Foreign References:}

16- Ahmed Abdel Fatah, Hesham Hegazy : Estimate the level of kinetic memory using an electronic scale proposal in relation to the decisions of judges kata in Karate, International scientific Journal, (2012) 
17- Hang, B : The design and implementation of on-line examination system. Proceedings of the International Symposium on, Computer Science and Society (ISCCS). Doi

10.1109/ISCCS.2011.68. (2011)

18- Martins. K: Design a Technical Test using interactive software to measure, the international Science Congress . (2010).
19- Timmers, C. F., Brabervan, d. B., \& van, d. B. Motivational beliefs, student effort, and feedback behavior in computer-based formative assessment. Computers \& Education, 60(1), (2013). 20- van, d. K., Eggen, T. J., Timmers, C. F., \& Veldkamp, B. Effects of feedback in a computer-based assessment for learning. Computers \& Education, 58(1). . (2012). 